\title{
Expert Meeting Report: Retrofit Implementation - A Neighborhood at a Time
}

Dianne Griffiths Consortium for Advanced Residential Buildings (CARB)

April 2012 


\begin{abstract}
NOTICE
This report was prepared as an account of work sponsored by an agency of the United States government. Neither the United States government nor any agency thereof, nor any of their employees, subcontractors, or affiliated partners makes any warranty, express or implied, or assumes any legal liability or responsibility for the accuracy, completeness, or usefulness of any information, apparatus, product, or process disclosed, or represents that its use would not infringe privately owned rights. Reference herein to any specific commercial product, process, or service by trade name, trademark, manufacturer, or otherwise does not necessarily constitute or imply its endorsement, recommendation, or favoring by the United States government or any agency thereof. The views and opinions of authors expressed herein do not necessarily state or reflect those of the United States government or any agency thereof.
\end{abstract}

Available electronically at http://www.osti.gov/bridge

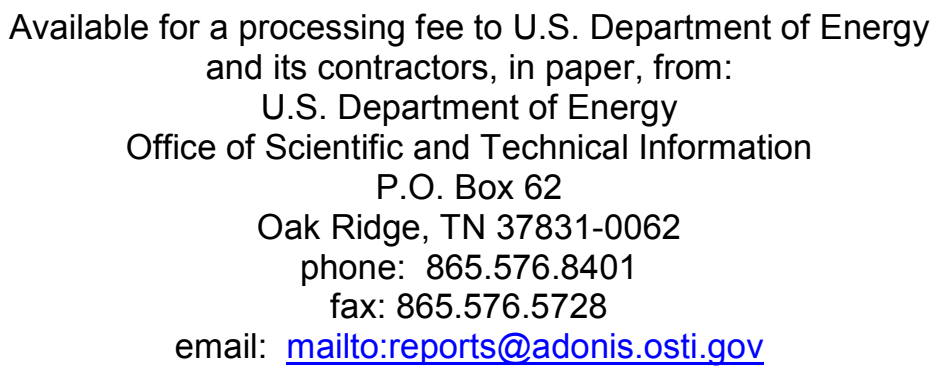

Available for sale to the public, in paper, from:

U.S. Department of Commerce

National Technical Information Service

5285 Port Royal Road

Springfield, VA 22161

phone: 800.553 .6847

fax: 703.605 .6900

email: orders@ntis.fedworld.gov

online ordering: http://www.ntis.gov/ordering.htm

Printed on paper containing at least $50 \%$ wastepaper, including $20 \%$ postconsumer waste 


\title{
Expert Meeting: Retrofit Implementation - A Neighborhood at a Time
}

\author{
Prepared for: \\ Building America \\ Building Technologies Program \\ Office of Energy Efficiency and Renewable Energy \\ U.S. Department of Energy \\ Prepared by: \\ D. Griffiths
}

Steven Winter Associates, Inc.

of the

Consortium for Advanced Residential Buildings (CARB)

61 Washington Street

Norwalk, CT 06854

Cheryn Engebrecht, Technical Monitor

NREL Task Order No. KNDJ-0-40342-02

April 2012 
[This page left blank] 


\section{Contents}

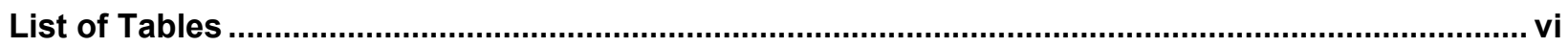

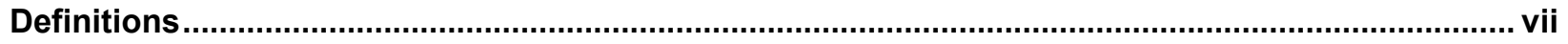

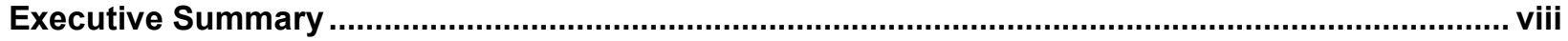

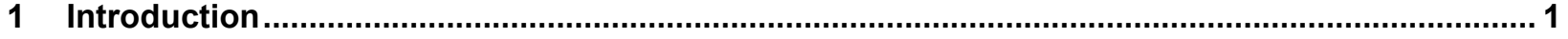

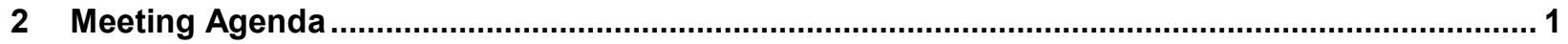

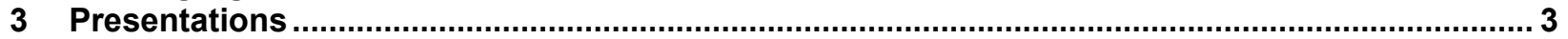

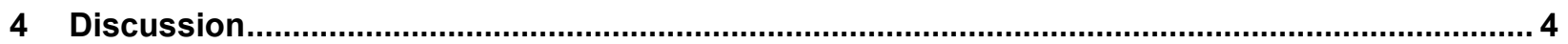

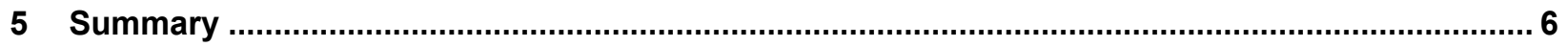

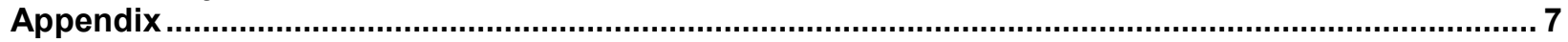




\section{List of Tables}

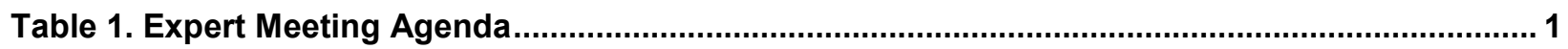

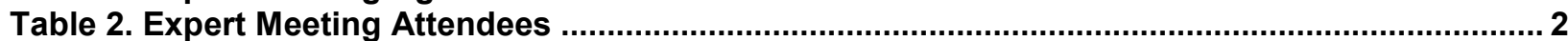

Unless otherwise noted, all tables were created by CARB. 


\section{Definitions}
ARBI
Alliance for Residential Building Innovation
CARB
Consortium for Advanced Residential Buildings
CBO
Community Based Organization
DOE
Department of Energy
NSP
Neighborhood Stabilization Program
NYSERDA
New York State Energy Research \& Development Authority
PARR
Partnership for Advanced Residential Retrofit
SWA
Steven Winter Associates, Inc. 


\section{Executive Summary}

On October 25, 2011, a Building America Expert Meeting was held to share the experiences of several different residential building retrofit implementation efforts. Representatives from three different Building America teams - Consortium for Advanced Residential Retrofit (CARB), Partnership for Advanced Residential Retrofit (PARR), and Alliance for Residential Building Innovation (ARBI — gave brief presentations followed by questions and discussion among the $40+$ meeting attendees. These attendees included representatives from utilities, energy program implementation firms, affordable housing agencies, and the financing industry.

The meeting was held in New York City at Pratt Manhattan Center. The Pratt Center for Community Development is a CARB member and their Retrofit NYC Block by Block program was a focus of the meeting. Presentations on activities in Pennsylvania, Illinois, Nevada, Colorado, and California were also given. Thus, the agenda represented a nationwide look at retrofit work in urban and suburban homes of different ages.

A key objective of this meeting was to provide a forum for retrofit providers to share information and exchange ideas on opportunities for improvement in production delivery of energy efficiency packages. 


\section{Introduction}

Residential construction booms over the decades have produced large tracts of homes of similar technical characteristics, i.e. age, style, size, and construction specifications. For example, row houses are a prevalent urban housing type characterized by shared walls and one to four apartments. There are more than 680,000 one- to four- family homes in New York City alone. Likewise, Levittown, Pennsylvania is comprised of 17,000 homes constructed in the 1950s using only six house plans. Thousands of ranch style homes were built in the Southwest in the 1960s.

A common hypothesis is that packages of retrofit measures can be defined and then applied on a broad scale across entire neighborhoods of similar homes. CARB has been involved in several initiatives including Block by Block in New York City, a scoping study in Levittown, Pennsylvania, neighborhood stabilization in Clark County, Nevada, and SmartRegs in Boulder, Colorado. PARR, together with team member Center for Neighborhood Technology (CNT), are characterizing the existing housing market in Illinois' Cook County and developing appropriate retrofit packages. ARBI is administering and providing technical support to three targeted large-scale retrofit programs in California.

\section{Meeting Agenda}

The meeting took place on October 25, 2011 from 9:30 AM to 2:00 PM, at Pratt Manhattan Center in New York City. The meeting agenda and attendees are presented in Tables 1 and 2, respectively.

Table 1. Expert Meeting Agenda

\begin{tabular}{|c|c|}
\hline Item & Presenter/Facilitator \\
\hline Welcome and Meeting Overview & $\begin{array}{l}\text { Dianne Griffiths, SWA } \\
\text { Wendy Fleischer, Pratt }\end{array}$ \\
\hline $\begin{array}{l}\text { Block by Block - Objectives, Accomplishments, } \\
\text { Challenges }\end{array}$ & Wendy Fleischer, Pratt \\
\hline Block by Block Audits - Early Findings & Carl Shapiro, SWA \\
\hline Audit and Utility Data Collection Challenges & $\begin{array}{l}\text { Liz Eisenberg, SWA } \\
\text { Deirdre Lizio, Pratt }\end{array}$ \\
\hline $\begin{array}{l}\text { Other Single Family Housing Projects } \\
\text { - Retrofitting Levittown } \\
\text { - Chicagoland Single Family Housing } \\
\text { Characterization } \\
\text { - Technical Challenges of Improving Uptake } \\
\quad \text { for Residential Retrofits in California } \\
\end{array}$ & $\begin{array}{l}\text { Emma Raymont, MaGrann } \\
\text { Larry Brand, Gas Technology Institute } \\
\text { Mark Berman, Davis Energy Group }\end{array}$ \\
\hline \multicolumn{2}{|l|}{ Lunch } \\
\hline
\end{tabular}


Other CARB Team Efforts

Boulder SmartRegs and Clark County NSP Lois Arena, SWA

Discussion on Technical Hurdles

All

DOE Building America Action Items

Dianne Griffiths, SWA

Table 2. Expert Meeting Attendees

\begin{tabular}{|c|c|}
\hline Company Name & Representative(s) \\
\hline Asian Americans for Equality & Kate Milkens \\
\hline Association of Energy Affordability & Marta Bell \\
\hline Bedford Stuyvesant Restoration Corporation & $\begin{array}{l}\text { Jedidah Baptiste } \\
\text { Rachel Dubin }\end{array}$ \\
\hline Bronx Overall Economic Development Corporation & Kate Shudeford \\
\hline Center for Working Families & $\begin{array}{l}\text { Stephen Edel } \\
\text { Anthony Ng }\end{array}$ \\
\hline Chhaya Community Development Corporation & Jessica Bartolini \\
\hline Community Environmental Center & Jay Ackley \\
\hline Con Edison & $\begin{array}{l}\text { Cristina Coltro } \\
\text { Gregory Elcock }\end{array}$ \\
\hline Conservation Services Group & $\begin{array}{c}\text { Christina Carton } \\
\text { Kyle Doody } \\
\text { Andrea Carvalho }\end{array}$ \\
\hline Davis Energy Group & Mark Berman \\
\hline Deutsche Bank Americas Foundation & Sam Marks \\
\hline Gas Technology Institute & Larry Brand \\
\hline Hanac Weatherization & Karen Butts \\
\hline KC Environmental, Inc. & Kevin Deeny \\
\hline Local Initiatives Support Corporation & $\begin{array}{c}\text { Colleen Flynn } \\
\text { Kathryn Prybylski }\end{array}$ \\
\hline Long Island Progressive Coalition & Lisa Tyson \\
\hline MaGrann Associates & Emma Raymont \\
\hline National Renewable Energy Laboratory (NREL) & Cheryn Engebrecht \\
\hline New York Mortgage Coalition & Elizabeth Malone \\
\hline $\begin{array}{l}\text { New York State Energy and Research Development } \\
\text { Authority }\end{array}$ & Mark Wyman \\
\hline NHS of Staten Island & Mark Hogan \\
\hline Pratt Center for Community Development & $\begin{array}{l}\text { Jay E. Emmingham } \\
\text { Wendy Fleischer } \\
\text { Adam Friedman } \\
\text { Simon Kates } \\
\text { Deirdre Lizio } \\
\text { Brooke Mayer } \\
\text { Gita Subramony }\end{array}$ \\
\hline
\end{tabular}




\begin{tabular}{|l|c|}
\hline Solar One & Jeff Irvine \\
\hline & \\
Steven Winter Associates, Inc. & Lois Arena \\
& Liz Eisenberg \\
& Dianne Griffiths \\
& Michael O'Donnell \\
Supportive Housing Network & Cariel Shapiro \\
\hline The Sallan Foundation, Inc. & Johanna Rose Walczyk \\
\hline
\end{tabular}

\section{Presentations}

The meeting's presentations have been compiled and are provided as Attachment A.

After a brief introduction by Dianne Griffiths, Pratt's Wendy Fleischer presented on the objectives, approach, accomplishments, and challenges of the Block by Block program. This program relies on community-based organizations to provide individualized assistance to homeowners to take advantage of several available incentive programs. Energy audits are performed through the incentive programs to be followed by energy retrofit implementation. An important finding thus far is that the energy audits vary significantly and appear to be skewed towards the incentives and/or expertise of the audit contractor. Another finding is that the program incentives and data collection forms are not designed for more urban housing that often includes multifamily and/or rental arrangements.

Within her presentation, Wendy invited Jedidah Baptiste, an outreach worker from Bedford Stuyvesant Restoration Corporation to speak for a few minutes on specific outreach challenges. Ms. Baptiste found that redefining some of the terminology associated with the process and educating homeowners were instrumental to the success of the program. For example, an "energy audit" is presented as an empowerment tool, informing homeowners about what is wrong with their home and what should be done, and prevents them from being taken advantage of by contractors. A "retrofit" is a package of things that can be improved. The intent is to encourage participation by speaking the community's language.

Steven Winter Associates' (SWA) Carl Shapiro then spoke on his efforts to model six of the homes that were audited in the Block by Block program and comparing model results to audit results. For the four similar homes constructed in the late $80 \mathrm{~s}$, the modeling supported the audit recommendations and energy savings. This was not the case for two 1920s-era homes. In these cases, the audit estimates of energy savings were much higher than the model predictions. Information is not adequate to fully understand the cause(s) for the differences.

SWA's Liz Eisenberg gave a brief presentation on the importance and difficulties in obtaining and interpreting utility data. 
Pratt's Deirdre Lizio presented on the audit data being consolidated into a database using the Salesforce tool. A demonstration of the database content and reporting capabilities was provided.

Emma Raymont of MaGrann Associates, a CARB member, presented a preliminary assessment of retrofit opportunities in Pennsylvania's Levittown community. Comprehensive audits were performed in 12 homes and modeling was done to evaluate retrofit packages. A significant challenge to large-scale retrofit work in this community is that $81 \%$ of the homes have been modified. Also, access and/or space for making air sealing, insulation, and equipment improvements in these rather small homes are very limited. Identifying a standard package will not be easy, but creating common, repeatable work scopes for the different model types/construction details is critical. Creating a common expectation for what energy retrofit work should include will help contractors and homeowners, and ultimately minimize up-front hand holding and back-end problems. Another opportunity may be gut rehab when home ownership changes. Approximately 500 homes change hands each year.

Larry Brand from the Gas Technology Institute presented on their "virtual neighborhood" approach. They have access to utility data as long as no individual household can be identified. They are using a variety of mapping tools and energy usage indexes to target the best retrofit opportunities.

Mark Berman of Davis Energy Group presented on their program efforts in California. Initial uptake has been slowed and they moved from a contractor-based approach to a more salesoriented approach. An important finding has been that people are concerned more about the contractor that is coming into their home than the program they are participating in. The job is to sell the contractor(s), not the program(s).

Lois Arena gave brief presentations on the work CARB has been doing in Boulder and Las Vegas. A key difference in the Boulder SmartRegs work is that mandatory regulations are moving the audit/retrofit market and Better Buildings Program funding is supporting program implementation. CARB has been evaluating the audit process and the appropriateness of the checklist tool that has been developed. In Las Vegas, the work involves retrofitting abandoned, foreclosed properties using Neighborhood Stabilization Program funding. CARB performed energy modeling to support the retrofit recommendations and created training materials to provide contractor education and guidance Analysis of 40 retrofit homes suggests that it is more cost effective to retrofit newer homes.

\section{Discussion}

Throughout the meeting, the audience was engaged with many questions and much discussion. While there were commonalities across the programs and projects discussed, there were also differences. The following is a summary of key discussion points:

The role of the third party intermediary between the homeowner and the retrofit contractor could be critical in establishing trust. The Energy Advisor in the Boulder program appears to 
be viewed as someone that can be trusted; in this program model, the advisor has no personal financial stake in selling retrofits (as opposed to contractors that do). In the Block by Block program, homeowners have often viewed the CBO in much the same way, however, in Boulder, energy efficiency regulations require homeowners to cut their use. Without those regulations, recruitment is more difficult. A NYSERDA representative noted that some contractors do not like the third party coming in as a sales person. However, the partners in the Block by Block program have been very grateful for the increased business. One consideration is that for the Block by Block program, the third party was introduced to a retrofit program that was already established, though few people are aware of them. The California program activity appears to be evolving towards having a third party salesperson role to address the trust concerns.

Improvements in health and/or comfort may motivate homeowners to implement home improvements more so than energy savings. These issues need to be integrated into the audit process (e.g., messaging about lowering asthma risk as opposed to improving ventilation may be more effective).

Several participants noted that it is important to find leaders as early adopters in a community or neighborhood. Testimonials by neighbors have been one of the most effective outreach strategies in the Block by Block project.

Construction characteristics and/or access issues can limit energy savings and/or increase costs, thus making $20 \%$ to $30 \%$ savings and $7-10$ year payback goals difficult to achieve.

With American homeowners spending \$300 billion per year on home improvements, more should be done to integrate energy efficiency upgrades into the replacement and home improvement industries.

Pricing for retrofit measures is highly variable and sometimes not provided. NREL is developing a national database that will be categorized by measure, but not housing type.

Energy assessments and retrofitting at home turnover represent an opportunity for increasing awareness. One consideration in designing any programs/legislation might be that realtors oppose anything that might interfere with the closing process.

Difficulty in obtaining utility data is a common problem. One attendee from the Long Island Progressive Coalition noted that they required that utility data be provided before and at the time of the audit. They believed that it gauges the seriousness of the homeowner and reduces the number of "tire kickers." The Internet site myenergy.com was suggested as another approach.

Our analyses suggest issues with modeling software overpredicting energy use in old, poorly insulated homes.

Setting up contractual relationships such as annual service agreements between contractors and homeowners to establish long term relationships and savings guarantees may be worthwhile. 
The comprehensiveness and quality of audits varies across and within programs. Often, training and education of auditing contractors is needed as well as quality assurance processes.

\section{Summary}

Presentations were given by representatives from three different Building America teams (CARB, PARR, and ARBI) on six different research efforts on the implementation of energy efficiency packages in neighborhoods of existing homes. Homes of different structural characteristics and age were represented as well as different regions of the country. The meeting's 40+ attendees included representatives from utilities, energy program implementation firms, affordable housing agencies, and the financing industry.

A key objective of the meeting was to provide a forum for retrofit providers to share information and exchange ideas on opportunities for improvement in production delivery of energy efficiency packages. This was accomplished through questions and open discussion throughout the meeting.

Additional research and demonstration is needed to document the potential represented by the programs that energy retrofit packages may be a cost-effective and expeditious way of scaling up energy retrofits. In addition, additional technical needs that could potentially be addressed by the DOE's Building America Program include:

A database of implementation cost information for common retrofit measures

Reliable energy modeling capability for older inefficient homes

Training curriculum for contractors and educational materials for homeowners. 


\section{Appendix}

Compiled presentations by

- Dianne Griffiths, SWA

- Wendy Fleischer, Pratt

- Carl Shapiro, SWA

- Liz Eisenberg, SWA

- Deirdre Lizio, Pratt

- Emma Raymont, MaGrann

- Larry Brand, Gas Technology Institute

- Mark Berman, Davis Energy Group

- Lois Arena, SWA

can be viewed at this link: Retrofit Implementation: A Neighborhood at a Time. 
buildingamerica.gov

\section{U.S. DEPARTMENT OF Energy Efficiency \& ENERY Renewable Energy}

